\title{
The Comparison of Lower Extremity Isokinetic Strength in Volleyball Players According to the Leagues
}

\author{
Cengiz Akarçeşme ${ }^{1, *}$ \& Sinem Hazır Aytar ${ }^{2}$ \\ ${ }^{1}$ Faculty of Sport Sciences, Gazi University, Ankara, Turkey \\ ${ }^{2}$ Faculty of Health Sciences, Department of Sports Sciences, Başkent University, Ankara, Turkey \\ *Correspondence: Faculty of Sport Sciences, Gazi University, Ankara, Turkey. Tel: 90-532-665-6093. E-mail: \\ cengizakarcesme@gazi.edu.tr
}

Received: August 2, 2018

Accepted: August 18, 2018 Online Published: August 24, 2018

doi:10.5430/wje.v8n4p111

URL: https://doi.org/10.5430/wje.v8n4p111

\begin{abstract}
The purpose of the study is to compare the ratio of lower extremity isokinetic hamstring/quadriceps ratio (H/Q), bilateral strength difference (BLD) and relative peak torques (RPT) in volleyball players according to the leagues. 101 volleyball players participated in the study (female $=34$, male $=25$ from $1^{\text {st }}$ league; female $=21$, male $=21$ from $2^{\text {nd }}$ league). Isokinetic extension and flexion of knee muscle strengths of the volleyball players were determined with isokinetic dynamometer. Independent $t$ test was used to compare volleyball players' flexor and extensor RPT, H/Q ratios and BLD according to their leagues. In the study conducted, it was determined that both male and female volleyball players playing the $1^{\text {st }}$ league had higher RPTs at $60^{\circ} \mathrm{s}^{-1}$ and $180^{\circ} \mathrm{s}^{-1}$ angular velocities. It was determined that volleyball players' BLD was within the desired limits, whereas their H/Q ratios were low. As a result, it was determined that the lower extremity isokinetic knee muscle RPT of the volleyball players playing in the $1^{\text {st }}$ League had better values than those playing in the $2^{\text {nd }}$ league, but these values were higher in the extension RPT. Since the essential requirement of volleyball is the jumping strength of the movements, this case may be related to the greater development of the extensor muscles.
\end{abstract}

Keywords: Isokinetic strength, bilateral strength difference, $\mathrm{H} / \mathrm{Q}$ ratio, volleyball

\section{Introduction}

Volleyball is a highly dynamic sports branch characterized by repetitive movements in a short period along with explosive movements and movement patterns involving jumping as well as sprinting in the field (Hedrick, 2007). It has been reported that in a five-set volleyball game played at the elite level 250-300 high intensity and explosive activities are exhibited (Seminati \& Minetti, 2013), and as for the attack and block techniques, it involves high-intensity vertical jump and landing movements (Kim \& Jeoung, 2016). It is emphasized that the muscles that perform flexion and extension movements in the knee joint are to have muscular activation at a sufficient level since the movement of the knee joint involves not only vertical jump and placement, but also the nature of the game, and these movements need to be changed rapidly (Nagai, Sell, House, Abt, \& Lephart, 2013).

In the high-intensity movement patterns, quadriceps (knee extensors) and hamstring muscle groups (knee flexors) participate in the primary level movements (Xaverova et al., 2015). Quadriceps muscles, which are also responsible for walking, running, dynamic stabilization of the knee joint, postural balance, and body weight, play a primary role in extensional movement (Kang, Kim, Lee, \& Kim, 2015). Knee flexors act as knee joint stabilizers during acceleration, divergence, deceleration and landing (Stolen, Chamari, Castagna, \& Wisloff, 2005). Therefore, that good level of knee flexor and extensor muscle strengths are considered to be particularly important in terms of preventing knee injuries and good sport performance (Zouita, Dziri, Ben Salah, \& Layouni, 2007; Bamac et al., 2008; Markou \& Vagenas, 2006; Aagaard, Simonsen, Trolle, Bangsbo, \& Klausen, 1995; Armour et al., 2004).

Isokinetic muscle strength assessment is a method which is a widely accepted and regarded as a golden standard for measuring the maximum torque strength (torque) of muscles involved in the movement of different parts of the body (Kim \& Jeoung, 2016; Xaverova et al., 2015; Colonna \& Ricciardi, 1998). Strength generated around a point or axis is called torque and is in units of newton/meter $(\mathrm{Nm})$. Angular velocities used in isokinetic tests are classified as 
$10-60^{\circ} \mathrm{s}^{-1}$ slow, $60-180^{\circ} \mathrm{s}^{-1}$ medium and $180-400^{\circ} \mathrm{s}^{-1}$ high (Kim \& Jeoung, 2016). In the current literature, isokinetic tests can be conducted at different angular velocities according to the speed of motion required by sports, but commonly used test speeds are $60^{\circ} \mathrm{s}^{-1}$ and $180^{\circ} \mathrm{s}^{-1}$. In addition, the ratio of hamstring muscle strength to quadriceps muscle strength $(\mathrm{H} / \mathrm{Q})$ and strength difference of left-right leg muscle (asymmetric/bilateral strength or muscle strength imbalance) are accepted as the criteria that determine the risk of injury to the knee joint (Rosene, Fogarty, \& Mahaffey, 2001; Aagaard, Simonsen, Trolle, Bangsbo, \& Klausen, 1995; Cheung, Smith, \& Wong, 2012). It is expected that the H/Q ratio in the concentric contraction is between $60-80 \%$ and this value increases as the angular velocity increases. That the H/Q ratio approximates $100 \%$ is interpreted as the increased functional capacity of the hamstring muscle group in the stabilization of the knee (Rosene, Fogarty, \& Mahaffey, 2001; Hewett, Myer, \& Zazulak, 2008). The accepted difference for the asymmetric strength is between 10-15\%, and further strength differences are considered as a risk factor for injury (Aagaard et al., 1995). Therefore, both H/Q and BLD have become important for clinicians and physical trainers in all sports branches (Mattes, Wollesen, \& Manzer, 2017).

In the rewieved literature, isokinetic strength of the extensor and flexor muscle groups in volleyball were investigated (Akarcesme, Aktug, Aka, \& Ibis, 2017; Bamac et al., 2008; Colonna \& Ricciardi, 1998; Kim \& Jeoung, 2016; Markou \& Vegenas, 2016; Mattes et al., 2017; Yenigun et al., 2008) yet no comparison of isokinetic strength values with respect to the leagues was found. The aim of this study is to compare the lower extremity isokinetic strength and other related variables in male and female volleyball players according to their leagues.

\section{Material and Method}

In the current study, anthropometric and isokinetic measurements were conducted. The athletes conducted all the tests between 9am-12am. The participant athletes had training 5-7 times a week according to their match schedule. Before the tests, the participants were informed about the test procedures and their approvals were obtained.

\subsection{Anthropometric Measurements}

The height was measured in the athletes' anatomical position at the inspiratory phase in the head frontal plane and the overhead surface touching the vertex point with a stadiometer (Holtain, England). Body weight, without sports clothes and footwear (Inbody 230, Korea) were measured when the athlete was on the anatomical standstill. Skinfold thickness was determined by with the skinfold caliper (Holtain, England) as suggested by Harrison et al. (1988) and the mean of these values was used in calculations. The body density was calculated though the formula of Durnin \& Womersley (1974) and then the percent body fat (BFP) was calculated through the Siri formula (Siri, 1956). Lean body mass (LBM) [Body weight - (Body weight)*BFP)] was determined as suggested by Nieman (1999).

\subsection{Isokinetic Strength Tests}

Isokinetic knee muscle strengths of lower extremity were determined through the isokinetic dynamometer (IsoMed 2000, Germany). Prior to the measurement, a 10 minute warm-up was performed at 50-60 rpm in a cycling ergometer at 50-60 rpm. After warming, the athlete was placed in the dynamometer at a $90^{\circ}$ hip joint angle, with the lateral femoral condyle and dynamometer shaft being on the same axis of rotation. For stabilization, the belts were fastened over the pelvis and the knee joint. The test protocol was applied concentrically on both legs at $60^{\circ} \mathrm{s}^{-1}$ and $180^{\circ} \mathrm{s}^{-1}$ angular velocities. Volleyball players were tested with 5 repetitions for $60^{\circ} \mathrm{s}^{-1}$ angular velocity and 15 repetitions for $180^{\circ} \mathrm{s}^{-1}$ angular velocity. After this test, the ratio of relative peak torque (RPT) to body weight (RPT/Body weight (kg)), H/Q ratio and BLD (Dominant (D)-NonDominant (ND) legs strength difference, \%) values were used in statistical analyses.

\subsection{Statistical Analysis}

The mean and standard deviation values of all the parameters examined were calculated and shown by means of the tables. After examining normality and homogeneity in the variables examined, the difference between the leagues was assessed by the independent $t$ test. $\mathrm{p}<0.05$ error level was used in all statistical procedures with SPSS 21 package program.

\section{Findings}

Anthropometric characteristics of volleyball players according to their leagues are given in table 1. All parameters examined were similar in the leagues for both gender ( $p>0.05$ ) except body weight which is higher in male volleyball players $(\mathrm{p}<0.05)$. 
Table 1. Anthropometric Characteristics of Volleyball Players According to Their Leagues (mean $\pm \mathrm{Sd})$

\begin{tabular}{lcccccc}
\hline & \multicolumn{3}{c}{ FEMALE } & \multicolumn{3}{c}{ MALE } \\
\cline { 2 - 7 } & League 1 & League 2 & p & League 1 & League 2 & p \\
\hline Age (year) & $21.9 \pm 4.2$ & $21.0 \pm 4.7$ & 0.495 & $24.3 \pm 5.4$ & $23.3 \pm 3.0$ & 0.195 \\
Height (cm) & $181.1 \pm 5.2$ & $179.2 \pm 5.2$ & 0.072 & $193.0 \pm 7.4$ & $193.2 \pm 5.5$ & 0.903 \\
Body Weight (kg) & $67.7 \pm 7.4$ & $66.6 \pm 6.3$ & 0.579 & $88.8 \pm 8.5$ & $83.2 \pm 6.9$ & $0.020^{*}$ \\
BFP (\%) & $16.9 \pm 3.9$ & $18.2 \pm 5.0$ & 0.334 & $10.5 \pm 3.3$ & $9.6 \pm 3.1$ & 0.387 \\
LBM (kg) & $57.4 \pm 6.5$ & $54.5 \pm 6.8$ & 0.165 & $78.2 \pm 7.6$ & $74.4 \pm 5.4$ & 0.097 \\
\hline
\end{tabular}

$* \mathrm{p}<0.05$. BFP: Body fat percentage, LBM: Lean body mass.

Table 2. Relative Peak Torque Strength Values of the Volleyball Players According to the Leagues (mean $\pm \mathrm{Sd}$ )

\begin{tabular}{|c|c|c|c|c|c|c|c|c|}
\hline \multirow{2}{*}{$\begin{array}{l}\text { Angular } \\
\text { Velocity }\end{array}$} & \multirow{2}{*}{ Legs } & \multirow{2}{*}{ Movement } & \multicolumn{3}{|c|}{ FEMALE } & \multicolumn{3}{|c|}{ MALE } \\
\hline & & & League 1 & League 2 & $\mathbf{p}$ & League 1 & League 2 & p \\
\hline \multirow{4}{*}{$60^{\circ} \mathrm{s}^{-1}$} & \multirow{2}{*}{$\mathrm{D}$} & Extension & $2.99 \pm 0.32$ & $2.58 \pm 0.30$ & $0.000 *$ & $3.57 \pm 0.45$ & $3.16 \pm 0.52$ & $0.007^{*}$ \\
\hline & & Flexion & $1.53 \pm 0.18$ & $1.38 \pm 0.19$ & $0.006^{*}$ & $1.90 \pm 0.29$ & $1.87 \pm 0.33$ & 0.750 \\
\hline & \multirow{2}{*}{ ND } & Extension & $2.88 \pm 0.34$ & $2.41 \pm 0.31$ & $0.000 *$ & $3.25 \pm 0.50$ & $2.93 \pm 0.54$ & $0.044^{*}$ \\
\hline & & Flexion & $1.41 \pm 0.16$ & $1.29 \pm 0.17$ & $0.008^{*}$ & $1.78 \pm 0.29$ & $1.79 \pm 0.31$ & 0.900 \\
\hline \multirow{4}{*}{$180^{\circ} \mathrm{s}^{-1}$} & \multirow{2}{*}{$\mathrm{D}$} & Extension & $2.18 \pm 0.23$ & $1.95 \pm 0.26$ & $0.001 *$ & $2.69 \pm 0.45$ & $2.16 \pm 0.19$ & $0.000 *$ \\
\hline & & Flexion & $1.18 \pm 0.18$ & $1.13 \pm 0.21$ & 0.292 & $1.47 \pm 0.24$ & $1.31 \pm 0.16$ & $0.017 *$ \\
\hline & \multirow{2}{*}{ ND } & Extension & $2.05 \pm 0.24$ & $1.79 \pm 0.22$ & $0.000 *$ & $2.51 \pm 0.43$ & $2.05 \pm 0.25$ & $0.000 *$ \\
\hline & & Flexion & $1.24 \pm 0.20$ & $1.07 \pm 0.25$ & 0.292 & $1.43 \pm 0.21$ & $1.31 \pm 0.16$ & $0.026^{*}$ \\
\hline
\end{tabular}

${ }^{*} \mathrm{p}<0.05$

The RPT results for D and ND legs obtained from the study are given in table 2. According to the comparison results; there were statistically significant differences in the female volleyball players belonging D and ND legs, $60^{\circ} \mathrm{s}^{-1}$ velocity extensor and flexor RPT values between leagues $(\mathrm{p}<0.05)$. There was a significant difference only in extension RPT values at $180^{\circ} \mathrm{s}^{-1}$ velocity for both $\mathrm{D}$ and ND legs in female volleyball players $(\mathrm{p}<0.05)$. For this angular velocity, the knee flexors RPT values were similar among the leagues ( $p>0.05)$. However, in all the variables examined, $1^{\text {st }}$ League athletes showed higher values than $2^{\text {nd }}$ League athletes. For male volleyball players, the RPT values of D and ND belonging to the leg at $60^{\circ} \mathrm{s}^{-1}$ showed a significant difference only for the extensors $(\mathrm{p}<0.05)$. However, at $180^{\circ} \mathrm{s}^{-1}$ velocity, extensor and flexor RPT values of $\mathrm{D}$ and ND belonging to the leg were significantly higher in the $1^{\text {st }}$ league male volleyball players $(\mathrm{p}<0.05)$.

Table 3. H/Q Ratios (\%) of the Volleyball Players According to the Leagues (mean $\pm \mathrm{Sd}$ )

\begin{tabular}{cccccccc}
\hline \multirow{2}{*}{$\begin{array}{l}\text { Angular } \\
\text { Velocity }\end{array}$} & \multirow{2}{*}{ Legs } & \multicolumn{3}{c}{ FEMALE } & \multicolumn{3}{c}{ MALE } \\
\cline { 2 - 8 } & League 1 & League 2 & p & League 1 & League 2 & p \\
\hline \multirow{2}{*}{$60^{\circ} \mathrm{s}^{-1}$} & $\mathrm{D}$ & $51.4 \pm 6.7$ & $53.4 \pm 5.4$ & 0.243 & $53.6 \pm 7.7$ & $59.4 \pm 7.6$ & $0.014^{*}$ \\
& $\mathrm{ND}$ & $49.8 \pm 7.4$ & $53.8 \pm 6.9$ & 0.049 & $55.4 \pm 7.6$ & $62.3 \pm 10.0$ & $0.012^{*}$ \\
$180^{\circ} \mathrm{S}^{-1}$ & $\mathrm{D}$ & $54.6 \pm 8.4$ & $58.0 \pm 7.9$ & 0.145 & $54.9 \pm 8.2$ & $61.0 \pm 6.9$ & $0.010^{*}$ \\
& $\mathrm{ND}$ & $61.1 \pm 11.6$ & $65.5 \pm 11.8$ & 0.185 & $58.4 \pm 9.8$ & $64.6 \pm 11$ & $0.046^{*}$ \\
\hline
\end{tabular}

$$
* \mathrm{p}<0.05
$$

The mean values of the H/Q ratios of the athletes and the statistical analysis results are given in table 3 . In female volleyball players, the $\mathrm{H} / \mathrm{Q}$ ratios in $\mathrm{D}$ and ND legs at both 60 and $180^{\circ} \mathrm{s}^{-1}$ velocity were similar to each other in both leagues $(\mathrm{p}<0.05)$. The statistical difference between these values in male volleyball players was significant $(\mathrm{p}$ $<0.05)$. 
Table 4. D-ND Legs BLD (\%) of the Volleyball Players According to Leagues (mean $\pm \mathrm{Sd}$ )

\begin{tabular}{cccccccc}
\hline \multirow{2}{*}{$\begin{array}{c}\text { Angular } \\
\text { Velocity }\end{array}$} & \multirow{2}{*}{ Movement } & \multicolumn{3}{c}{ FEMALE } & & \multicolumn{3}{c}{ MALE } \\
\cline { 3 - 8 } & & League 1 & League 2 & p & League 1 & League 2 & p \\
\hline \multirow{2}{*}{$60^{\circ} \mathrm{s}^{-1}$} & Extension & $6.4 \pm 4.6$ & $7.9 \pm 5.5$ & 0.185 & $9.0 \pm 7.5$ & $7.6 \pm 6.5$ & 0.500 \\
& Flexion & $7.5 \pm 6.8$ & $6.8 \pm 5.8$ & 0.296 & $6.4 \pm 4.8$ & $8.4 \pm 7.6$ & 0.282 \\
$180^{\circ} \mathrm{s}^{-1}$ & Extension & $6.9 \pm 5.9$ & $9.6 \pm 4.4$ & 0.077 & $7.9 \pm 6.1$ & $6.5 \pm 5.9$ & 0.438 \\
& Flexion & $9.5 \pm 5.7$ & $8.0 \pm 7.1$ & 0.383 & $8.3 \pm 8.4$ & $8.4 \pm 6.7$ & 0.979 \\
\hline
\end{tabular}

BLD values are given in table 4. According to the results obtained, for D and ND legs, knee extensor and flexor BLD are similar both male and female volleyball players according to the leagues at velocities $60^{\circ} \mathrm{s}^{-1}$ and $180^{\circ} \mathrm{s}^{-1}(\mathrm{p}>0.05)$.

\section{Discussion}

In all sports branches, the strength balance between the muscles is more important than the highest strength present. The reason is that the muscles have the highest strength available to them, and they can exhibit the weakest strength of the muscle and muscle groups they have (Astrand, Rodahl, Dahl, \& Stromme, 2003). This muscle balance is extremely important in the lower extremity at the H/Q ratio and in the bilateral leg extensor and flexor muscles. The aim of this study is to determine the difference between the isokinetic knee strengths of both volleyball players and knee muscle strength balances.

Although the upper extremity visually seems to do much work in volleyball (Yenigun et al., 2008), as volleyball involves jumping, sudden change of direction, deception, stopping, sudden movements, high level balance and sprint movements (Almeida \& Soares, 2003; Dal Pupo, Detanico, \& Dos Santos, 2012; Ibis, Iri, \& Aktug, 2015; Akarcesme, Aktug, Aka, \& Ibis, 2017). The lower extremity strength is more important than the upper extremity strength. Therefore, low strength of knee flexor-extensor muscle and strength imbalance between these muscles may lead to low performance of the basic movements of volleyball (spike, block and receive).

There are not any studies in the literature evaluating the isokinetic strength of volleyball players in different leagues while there are some studies on evaluating the isokinetic strengths of the athletes in different leagues on soccer players. In the study conducted, it was determined that volleyball players playing in the $1^{\text {st }}$ league had higher isokinetic knee extensor and flexor strengths than those playing in the $2^{\text {nd }}$ League, however the H/Q ratios were higher in volleyball players playing in $2^{\text {nd }}$ league. In a similar study on soccer players, it was determined that the eccentric and concentric flexor strengths in those playing the $1^{\text {st }}$ and $2^{\text {nd }}$ were higher than those playing in the $3^{\text {rd }}$ league and the lower extremity eccentric and concentric extensor strengths of the players playing in the $1^{\text {st }}$ league were higher than those playing $2^{\text {nd }}$ in the $3^{\text {rd }}$ league. It was found that concentric H/Q ratio was similar in the 1 st and $2^{\text {nd }}$ leagues, yet it was lower in the $3^{\text {rd }}$ league and the eccentric H/Q ratio was higher in the $2^{\text {nd }}$ than the others (Ozberk, Coskun, Akin, \& Korkusuz, 2009). In a study on elite, sub-elit and amateur soccer players' lower extremity concentric extensor and flexor muscle strengths, they reported that elite soccer players had higher flexor muscle strengths (Cometti, Maffiuletti, Pousson, Chatard, \& Maffulli, 2001). Cometti, Maffiuletti, Pousson, Chatard, \& Maffulli (2001) also found that amateur soccer players had lower H/Q ratios than professional soccer players. In another study, Gissis et al. (2006) found that Greek elite soccer players generated higher isometric strengths than sub-elite soccer players.

In the above studies, the higher isokinetic peak torques of the athletes in the upper league is similar to the results of the current study, whereas the H/Q ratio in the current study is higher in the lower league, which is not parallel with the current literature. In addition to jumping and ball-striking movements that will increase the strength of the muscles in soccer, the flexor muscles, such as sprint, are in motion to increase muscle strength. In volleyball, many of movements are performed with vertical or horizontal jump performance. In general, it is necessary to actively contract the muscles of the quadriceps group in the lower leg in order to be able to perform the motion away from the ground when the jump motion is examined in general (Walsh, Boling, McGrath, Blackburn, \& Padua, 2012). This can lead to the extensor muscles to become stronger in volleyball. The number of training sessions of the $1^{\text {st }}$ league volleyball players participate in is higher than those playing in the $2^{\text {nd }}$ league therefore accordingly the number of jumping increases which may cause an increase in the extensor strength and decrease in their H/Q ratios of the players playing in the $1^{\text {st }}$ league. This low H/Q ratio found in volleyballs may also cause increased knee injury sensitivity with particular emphasis on stress on the anterior cruciate ligament (ACL) due to decreased joint stability (Magalhaes, Oliveira, Ascensao \& Soares, 2004). 
In the current study, it was determined that the BLD of the volleyball players is similar between the leagues and within the desired limits. In a similar study, it was determined that the isokinetic $\mathrm{H} / \mathrm{Q}$ ratios of elite female volleyball players were low, while BLD was found to be within the desired limits (Akarcesme, Aktug, Aka, \& Ibis, 2017). Akarcesme, Aktug, Aka and Ibis (2017) have associated the desired level of BLD with the use of volleyball players equally in both legs during training and performing a correct strength exercise. In another study, Magalhaes, Oliveira, Ascensao and Soares (2004) determined the difference between the isokinetic H/Q ratio and BLD of soccer players with volleyball players. The H/Q ratio of volleyball players was lower than the soccer players and BLD was among the desired levels. When the findings of study on amateur soccer, basketball and volleyball players are examined, it is seen that volleyball players' H/Q ratios and BLD are within the desired levels. The results of the studies on volleyball players above can support the results of the current study; besides, it can be said that the volleyball players use and strengthen both legs equally.

\section{Conclusion}

As a result, it is found that; as the level of the league in volleyball increases, isokinetic knee muscle strength increases and H/Q ratio decreases. In order to achieve high level and repetitive movements which volleyball strongly requires the coaches should prepare a training program that focuses especially on knee flexor muscles to increase $\mathrm{H} / \mathrm{Q}$ ratio. Moreover, it is crucial to improve bilateral leg strength and H/Q muscle ratio in order to enhance second league volleyball players' individual performance and decrease the possibility of injuries on lower extremity. Therefore, it is recommended that second league coaches and players should be informed about isokinetic strength. Coaches can include some lower extremity strength exercises such as thera band, Nordic curl and leg curl in their practice schedule, which can raise players' isokinetic strength level to desired level.

\section{References}

Aagaard, P., Simonsen, E. B., Trolle, M., Bangsbo, J., \& Klausen, K. (1995). Isokinetic hamstring/quadriceps strength ratio: influence from joint angular velocity, gravity correction and contraction mode. Acta Physiologica Scandinavica, 154(4), 421-427. https://doi.org/:10.1111/j.1748-1716.1995.tb09927.x

Akarcesme, C., Aktug, Z., Aka, H., \& Ibis, S. (2017). An investigation of leg and shoulder muscle strength ratios of elite female volleyball players. Turkish Journal of Sport and Exercise, 19(2), 284. https://doi.org/10.15314/tsed.337441.

Almeida TA, S. E. (2003). Nutritional and anthropometric profile of adolescent volleyball athletes. Revista Brasileira Medicina do Esporte, 9(4), 198-203. https://doi.org/10.1590/S1517-86922003000400002.

Armour, T., Forwell, L., Litchfield, R., Kirkley, A., Amendola, N., \& Fowler, P. J. (2004). Isokinetic evaluation of internal/external tibial rotation strength after the use of hamstring tendons for anterior cruciate ligament reconstruction. The American Journal of Sports Medicine, 32(7), 1639-1643. https://doi.org/10.1177/0363546504263405

Astrand P. O., R. K., Dahl A. H., \& Stromme BS. (2003). Textbook of Work Phyiology: Human Kinetics.

Bamac, B., Colak, T., Ozbek, A., Colak, S., Cinel, Y., \& Yenigun, O. (2008). Isokinetic Performance in Elite Volleyball and Basketball Players. Kinesiology, 40(2), 182-188.

Cheung, R. T., Smith, A. W., \& Wong del, P. (2012). H:q ratios and bilateral leg strength in college field and court sports players. Journal of Human Kinetics, 33, 63-71. https://doi.org/10.2478/v10078-012-0045-1

Colonna, S., \& Ricciardi, F. (1998). A comparison between the isokinetic knee strength and jump height in a group of volleyball players. Medicina Dello Sport, 51(2), 207-212. https://doi.org/10.1515/humo-2017-2022

Cometti, G., Maffiuletti, N. A., Pousson, M., Chatard, J. C., \& Maffulli, N. (2001). Isokinetic strength and anaerobic power of elite, subelite and amateur French soccer players. International Journal of Sports Medicine, 22(1), 45-51. https://doi.org/10.1055/s-2001-11331

Dal Pupo, J. D. D., \& Dos Santos SG. (2012). Kinetic parameters as determinants of vertical jump performance. Brazilian Journal of Kinathropometry and Human Performance, 14(1), 41-51. https://doi.org/10.5007/1980-0037.2012v14n1p41

Durnin, J. V. G. A., \& Womersley, J. (1974). Body Fat Assessed from Total-Body Density and Its Estimation from Skinfold Thickness - Measurements on 481 Men and Women Aged from 16 to 72 Years. British Journal of Nutrition, 32(1), 77-97. https://doi.org/10.1079/Bjn19740060 
Gissis, I., Papadopoulos, C., Kalapotharakos, V. I., Sotiropoulos, A., Komsis, G., \& Manolopoulos, E. (2006). Strength and speed characteristics of elite, subelite, and recreational young soccer players. Research in Sports Medicine, 14(3), 205-214. https://doi.org/10.1080/15438620600854769

Harrison, G. G., Buskirk, E.R., Carter, J.E.L., Johnson, F.E., \& Pollock, M.L., et al. (1988). Skinfold Thicknesses and Measurement Technique. Anthropometric Standartization Referance Manuel. Champain: Human Kinetics.

Hedrick, A. (2007). Training for high level performance in women's collegiate volleyball: Part I training requirements. Strength and Conditioning Journal, 29(6), https://doi.org/10.1519/1533-4295(2007)29[50:Tfhlpi]2.0.Co;2

Hewett, T. E., Myer, G. D., \& Zazulak, B. T. (2008). Hamstrings to quadriceps peak torque ratios diverge between sexes with increasing isokinetic angular velocity. Journal of Science and Medicine in Sport, 11(5), 452-459. https://doi.org/10.1016/j.jsams.2007.04.009

Ibis, S., Iri, R., \& Aktug, Z. B. (2015). The effect of female volleyball players' leg volume and mass on balance and reaction time. Journal of Human Sciences, 12(2), 1296-1308. https://doi.org/10.14687/ijhs.v12i2.3319

Kang, D. Y., Kim, H. S., Lee, K. S., \& Kim, Y. M. (2015). The effects of bodyweight-based exercise with blood flow restriction on isokinetic knee muscular function and thigh circumference in college students. Journal of Physical Therapy Science, 27(9), 2709-2712. https://doi.org/10.1589/jpts.27.2709

Kim, C. G., \& Jeoung, B. J. (2016). Assessment of isokinetic muscle function in Korea male volleyball athletes. Journal of Exercise Rehabilitation, 12(5), 429-437. https://doi.org/10.12965/jer.1632710.355

Magalhaes, J., Oliveira, J., Ascensao, A., \& Soares, J. (2004). Concentric quadriceps and hamstrings isokinetic strength in volleyball and soccer players. The Journal of Sports Medicine and Physical Fitness, 44(2), 119-125.

Markou, S., \& Vagenas, G. (2006). Multivariate isokinetic asymmetry of the knee and shoulder in elite volleyball players. European Journal of Sport Science, 6(1), 71-80. https://doi.org/10.1080/17461390500533147

Mattes, K., Wollesen, B., \& Manzer, S. (2018). Asymmetries of Maximum Trunk, Hand, and Leg Strength in Comparison to Volleyball and Fitness Athletes. The Journal of Strength \& Conditioning Research, 32(1), 57-65. https://doi.org/10.1519/JSC.0000000000002183

Nagai, T., Sell, T. C., House, A. J., Abt, J. P., \& Lephart, S. M. (2013). Knee proprioception and strength and landing kinematics during a single-leg stop-jump task. Journal of Athletic Training, 48(1), 31-38. https://doi.org/10.4085/1062-6050-48.1.14

Nieman, D. (1999). Exercise testing and prescription: A health-related approach: Mountain View, CA: Mayfield.

Ozberk, Z. N., Coskun, Ö. Ö., Akin, S., \& Korkusuz, F. (2009). Isokinetic strength of quadriceps and hamstring muscles in soccer players playing in different leagues. Turkiye Klinikleri Journal of Sports Sciences, 1(1), $17-23$.

Rosene, J. M., Fogarty, T. D., \& Mahaffey, B. L. (2001). Isokinetic hamstrings: Quadriceps ratios in intercollegiate athletes. Journal of Athletic Training, 36(4), 378-383.

Seminati, E., \& Minetti, A. E. (2013). Overuse in volleyball training/practice: A review on shoulder and spine-related injuries. European Journal of Sport Science, 13(6), $732-743$. https://doi.org/10.1080/17461391.2013.773090

Siri, W. E. (1956). The gross composition of the body. Advances in Biological and Medical Physics, 4, $239-280$. https://doi.org/10.1016/B978-1-4832-3110-5-50011-X

Stolen, T., Chamari, K., Castagna, C., \& Wisloff, U. (2005). Physiology of soccer - An update. Sports Medicine, 35(6), 501-536. https://doi.org/10.2165/00007256-200535060-00004

Walsh, M., Boling, M. C., McGrath, M., Blackburn, J. T., \& Padua, D. A. (2012). Lower extremity muscle activation and knee flexion during a jump-landing task. Journal of Athletic Training, 47(4), 406-413. https://doi.org/10.4085/1062-6050-47.4.17

Xaverova, Z., Dirnberger, J., Lehnert, M., Belka, J., Wagner, H., \& Orechovska, K. (2015). Isokinetic Strength Profile of Elite Female Handball Players. Journal of Human Kinetics, 49(1), 257-266. https://doi.org/10.1515/hukin-2015-0128

Yenigun O, C. T., Bamac B., Yenigun N., Ozbek A., Bayazıt B., \& Colak E. (2008). Voleybol oyuncularının diz ekleminin izokinetik performans değerleri ve hamstring (fleksör)/ Quadriceps (ekstansör) oranlarındaki 
farkl1l1kların belirlenmesi. Journal of Human Sciences, 5(1), 1-13.

Zouita, A., Dziri, C., Ben Salah, F. Z., \& Layouni, R. (2007). Comparison of isokinetic muscle strength and ratio hamstring/quadriceps between Tunisian athletes. Science \& Sports, 22(5), 196-200. https://doi.org/10.1016/j.scispo.2007.08.001 